\title{
The Current Status of SEZ, India
}

\author{
S. Chandrachud ${ }^{1}$, Asst. Professor, VELS University, Chennai \\ Dr. N. Gajalakshmi ${ }^{2}$, Asst. Prof. S.D.N.B.V College for women, Chennai
}

\section{Introduction}

SEZ, the acronym of Special Economic Zone. SEZ is a geographical region that has economic laws different from a country's generally applicable economic laws, for the purpose of economic development and growth with the help of foreign investment. Literally SEZ means, a geographically demarcated region that has economic laws that are more liberal than the country's typical economic laws and where all the units therein have specific privileges. SEZs are specifically delineated duty-free enclaves and are deemed to be foreign territory for the purposes of trade operations, duties and tariffs.1

The Present paper attempts to measure the level of economic quake felt by Indian economy in the $21^{\text {st }}$ century with the subheading SEZ - In Global context, SEZ - In Indian context, Comparison of State-wise approvals of SEZ and Sector-wise approval of SEZ and concluded with role of SEZ in Units Approvals, Export performance, Employment generation and Investment.

\section{SEZ - In Global Context}

According to world bank estimate, as on 2007, there are 3000 projects taking place in SEZs across 120 countries worldwide and it has been grown in reap and bounds in the recent past. In 1896, the first industrial Park was set up in Manchester, called Free Trade Zone, designed to promote the free trade, conceptually improved by Hong Kong during the Post-Second world War, created economic quake elsewhere thereafter. In 1929, the first Special Economic Zone which was called as Special Zone was introduced in Spain with the intention of improving the exports by value addition to the raw materials available in that country, conceptually improved by Deng Xiaoping, revolutionary veteran of China, for the past three decades, gave an economic quake to the concept of SEZ from1979. He used the SEZ as the economic quake to attain the success of his liberalized economic policies. Later the other developing countries, like UAE, Jordan, Philippines, Malaysia, Russia, Kazakhstan and South Korea are also chosen the Chinese path in their economies in terms of economic liberalization. Even most of the countries in south Asia - Nepal, Bangladesh, Sri Lanka and Pakistan have tried to promote their export.

\section{SEZ - In Indian Context}

Right from the beginning of $21^{\text {st }}$ century, India has progressively opened up its economy to face the new challenges effectively and utilize the opportunities positively. Considering the importance to enhance foreign investment and promote exports from the country. Realizing the need that the field of business play must be available to domestic enterprises and manufacturers to be competitive globally, the government had announced the introduction of Special Economic Zones (SEZs) policy on April 2000, through a revision in the Export and Import policy (EXIM) 1997-2002. The objective of SEZs include making available goods and services free of taxes and duties supported by integrated infrastructure for export production, quick approval mechanisms, and a package of incentives to attract foreign and domestic investments for promoting exports. The SEZ policy suffers from lack of central legislation, rigid labour laws and multi clearance of approval etc. In order to overcome such lacunae, the government of India enacted SEZ act 2005 to give a long term and stable policy framework with minimum regulation. It came into force from February 2006. The main objectives of the SEZs are:
(a) Generation of additional economic activity;
(b) Promotion of exports of goods and services;
(c) Promotion of investment from domestic and foreign sources;
(d) Creation of employment opportunities;
(e) Development of infrastructure facilities.2

In fact, India was the first Asian country to recognize the importance and effectiveness of Export Processing Zone (EPZ) and the first EPZ came into being in 1965 in Kandla, Gujarat. But, since then there has not been done much to the strengthening of EPZs in India. In 2000, therefore, the government replaced the earlier regime of EPZ by a new scheme of SEZs, which encompassed a number of potential benefits that were missing in the earlier scheme. In May 2005, the SEZ Act2 was passed by the Parliament and SEZ Rules 3 came into force from February 10, 2006, which not only simplified procedures but also extended single window 
clearance for matters relating to Central as well as state governments. The SEZ Rules provide for different minimum land requirement for different class of SEZs. The promotion of SEZs is expected to tackle wide range of structural bottlenecks created by monetary, fiscal, taxation, trade, tariff and labour policies, aside from overcoming complex procedures and infrastructure deficiencies (Aggarwal, 2006). It has been argued that since development of infrastructure requires huge capital investment and as implementation of structural reforms is time-consuming process, the establishment of SEZs would be the only realistic strategy governing the process of industrialization. Although SEZs offer numerous benefits, there are also various positive as well as negative features associated with the establishment of SEZs in India. It is, therefore, essential to analyse not only the potential benefits of SEZs but also the likely impact of establishment of SEZs on agricultural production, employment, water and food security.

\section{Salient Features of SEZ Act}

SEZs in India are not only expected to bring large flow of foreign direct investment but also domestic investment, which will help in generating additional economic activity in the form of creating employment opportunities, infrastructure development and enhancing productive capacity as well as capabilities. The salient features of the SEZ Act mainly revolve around

a) Satisfying the needs of all major stakeholders in an SEZ, including developers, operators, suppliers, residents, etc.,

b) Making provisions of single window clearance mechanism

c) Providing attractive fiscal incentive package,

d) Establishing free trade and warehousing zones with a view to develop internationally competitive infrastructure facilities to augment import and export of commodities

e) Setting up of off shore banking units, and

f) Facilitating public private participation towards development of infrastructure.

The SEZ Rules provide for different minimum land requirement for different class of SEZs. Every SEZ is divided into a processing area where alone the SEZ units would come up and the non-processing area where the supporting infrastructure is to be created. The main purpose of framing SEZ rules to provide:

a) " Simplified procedures for development, operation, and maintenance of the Special Economic Zones and

for setting up units and conducting business in SEZs;

b) Single window clearance for setting up of an SEZ;

c) Single window clearance for setting up a unit in a Special Economic Zone;

d) Single Window clearance on matters relating to Central as well as State Governments;

e) Simplified compliance procedures and documentation with an emphasis on self certification

In order to attract investments into the SEZs in India, number of incentives and facilities have been offered to the SEZs are duty free import and domestic procurement of goods for development, operation and maintenance of SEZ units, 100\% Income tax exemption on export income for SEZ units under section 10AA of the Income Tax Act for first 5 years thereafter 50\% of the ploughed back export profit for next 5 years, exemption from minimum alternate tax under section 115JB of the Income Tax Act, External Commercial borrowing by SEZ units up to US $\$ .500$ million in a year without any maturity restrictions through recognized banking channels, exemption from Central Sales Tax, single window clearance for Central and state level approvals and exemption from state sales tax and other levies as extended by the respective State Government.

In addition to that there are certain major incentives and facilities available to SEZ developers, right from, exemption from customs and excise duties for development of SEZs for authorized operations approved by the BOA, Income tax exemption on the income derived from the business of development of the SEZ in a block of 10 years in 15 years under section 80-IAB of the Income Tax Act, exemption from minimum alternate tax under 115JB of the Income Tax Act, exemption from dividend distribution tax under Section $115 \mathrm{O}$ of the Income Tax Act, exemption from Central Sales Tax (CST) up to exemption from Service Tax (Section 7, 26 and Second schedule of SEZ Act) etc. (GOI, 2011)

A successful SEZ investment in India would benefit by noting the following investment related issues:

a) relief and rehabilitation of the displaced people is a serious issue;

b) investors need to attract the attention of state governments, and the investors and the concerned state governments must discover synergies, which they find mutually worth pursuing;

c) investors should stay out of partisan politics because ruling parties frequently lose power in India; and

d) it helps if the concerned state has ministers in central ministries who can help clear infrastructure projects such as roads, ports, airports and rail connections favorable to investors in that state. 


\section{Review of Literature}

a) Madani (1999) reports that a 1981 survey in the Dominican republic found that SEZ wages were the main source of income for $38 \%$ of Women working in the zones and that almost half of them were single, divorced or widows

b) "Quality practices are investment in competitive resources and capabilities which bring competitiveness to the firm, by enhancing reliability, in the eye of customers through superior firm performance" Krajewski and Ritzman (1996), Khalil (2000)

c) "the SEZ wages reported to be lower than the wages in the Non-SEZ area" Pakistan (Kemel 2001) and Haiti (Heron 2004)

d) "Management capacity as an investment in resources and capabilities makes progress towards competitiveness of a firm”. Priyanto (2006), Verma (2002)

e) "The production capacity and utilisation is an investment in competitive resources that provide competitiveness to the firm by superior performance." Bavani (2006)

f) "Firms benefit from local production externalities, which exist when a firm's production possibilities depend on the actions of other firms located in the same region." Hanson (2001), Henderson (2003), and Agarwal (2004).

g) "Vision is one of the abilities of the entrepreneur to steer the firm ahead in the competitions" Vasant Desai (2006)

h) "Providing hassle free environment to run business is one of the objectives of SEZ exim policy." Madani (1999) and Exim policy (2002-2007), SEZ Act, Ministry of Commerce, India

i) "Ability to procure goods from outside is one of the prinicipal benefits of creating export" Agarwal (2004) and Ministry of India.

j) "Special Economic Zones in India - An Introduction" ASIEN, 106, January 2008 Jona Aravind Dohrmann,

k) Location strategy for competitiveness of Special Economic Zones in India - A Generic Framework, by Tarun Dhingra, Dr. Ambalika Sinha, and Dr. Tripti Singh ${ }^{3}$

\section{State wise Break up of SEZ}

Different states have different SEZ stories to tell. While some have done exceedingly well, others seem to be going nowhere.

\section{Table 1 State wise distribution of SEZ Approvals}

\begin{tabular}{|c|c|c|c|}
\hline State or Union Territory & Formal approvals & In Principle approval & Notified SEZ \\
\hline Andra Pradesh & 109 & 6 & 76 \\
\hline Chandigarh & 2 & 0 & 2 \\
\hline Chattisgarh & 1 & 1 & 1 \\
\hline Delhi & 3 & 0 & 0 \\
\hline Dadra \& Nagar Haveli & 2 & 0 & 1 \\
\hline Goa & 7 & 0 & 3 \\
\hline Gujarat & 47 & 7 & 32 \\
\hline Hariyana & 46 & 3 & 35 \\
\hline Jharkhand & 1 & 0 & 1 \\
\hline Karnataka & 62 & 1 & 41 \\
\hline Kerala & 29 & 0 & 20 \\
\hline Madhya Pradesh & 19 & 2 & 6 \\
\hline Maharshta & 103 & 16 & 64 \\
\hline Nagaland & 2 & 0 & 1 \\
\hline Orrisa & 10 & 1 & 5 \\
\hline Pondicherry & 1 & 1 & 0 \\
\hline Punjab & 8 & 0 & 2 \\
\hline Rajasthan & 10 & 1 & 10 \\
\hline Tamilnadu & 69 & 6 & 53 \\
\hline Uttar Pradesh & 34 & 1 & 21 \\
\hline Uttarkhand & 2 & 0 & 1 \\
\hline West Bengal & 20 & 3 & 11 \\
\hline Grand Total & 588 & 49 & 386 \\
\hline
\end{tabular}

Source: Ministry of Commerce and Industry, SEZ in India, GOI 
Figure : 1 Statewise distribution of SEZ Approvals

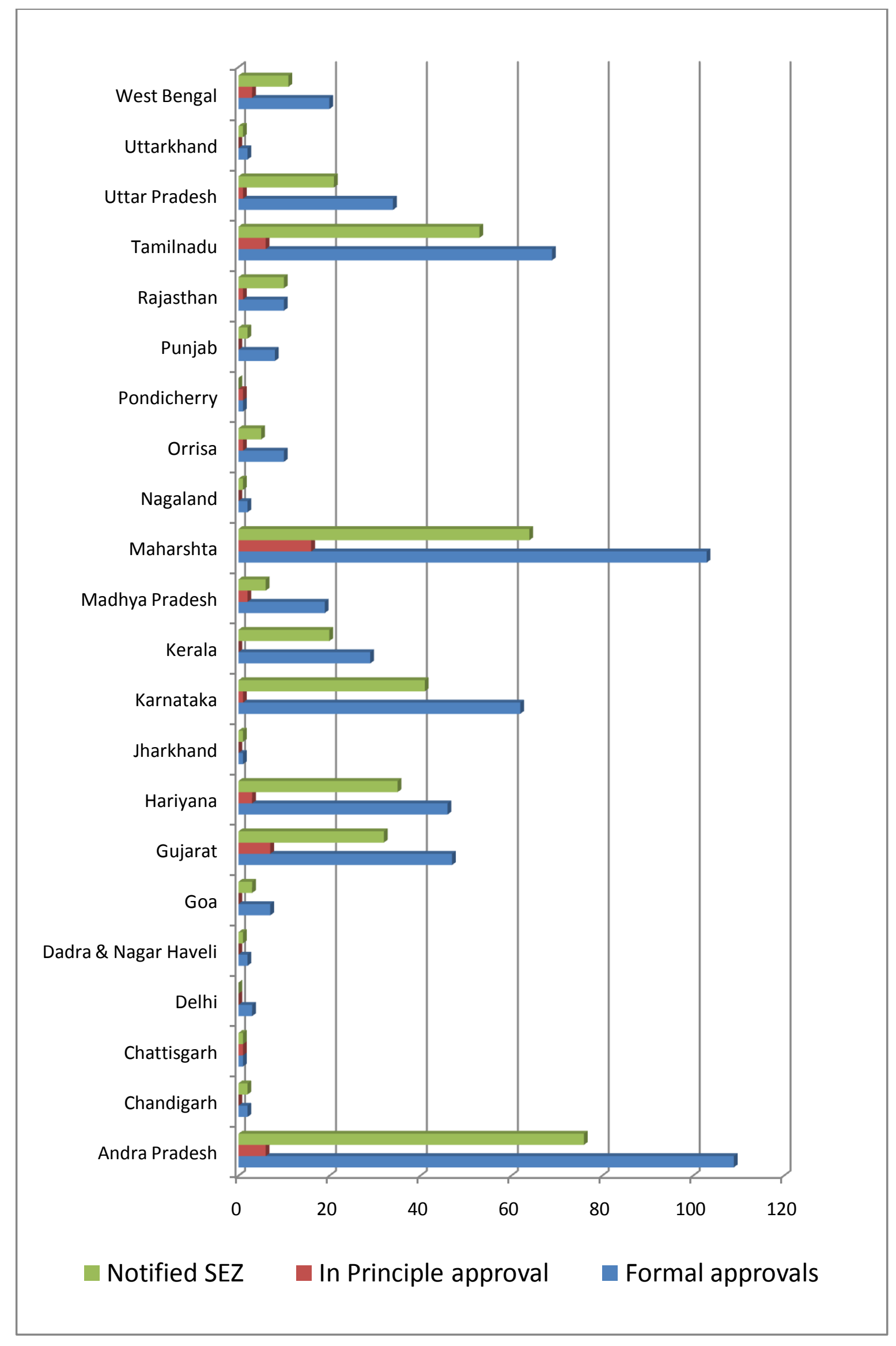


Due to wide range of incentives, facilities and many other relaxations amended in SEZs, majority of the states in the country are motivated to set up SEZs to enjoy the advantages generated through these zones. Presently, there were 588 formal approvals of SEZ across 22 states in the country. 3 Out of these 386 SEZs are notified. Among Various states Andra Pradesh ranks first in the country with 4700 hectares of area under SEZs. The Other States like Tamilnadu, Maharashta and Gujarat are likely to have significant area under SEZ.

It is to be noted that Out of total 588 approvals the selected states such as Andra Pradesh, Tamilnadu, Gujarat, Uttar Pradesh, West Bengal, Kerala, Karnataka, Madya Pradesh, Hariyana and Maharastra have contributed 499 approvals and the rest of the states contributed for remaining 89 approvals. It is unfortunate that some of the states have not shown any interest in SEZ. The following table shows state wise distribution of SEZ approvals.

\section{Sector wise Break up of SEZ}

Those 588 formal approvals of SEZs, distributed among 28 industrial sectors in the country. Out of this 386 SEZs are Notified. Among several industries IT/ITES ranks first in the country, nearly 55\% of the the total formal approvals and other industries like Biotech, petro chemical, Textiles, FTWZ and Gems \& Jewellary 4 likely to have significant share under SEZ.

Table: 2 Sector wise distribution of SEZ Approvals

\begin{tabular}{|c|c|c|c|}
\hline Sectors & Formal approvals & In Principle approval & Notified SEZ \\
\hline Agro & 6 & 2 & 5 \\
\hline Airport based multiproduct & 4 & 0 & 0 \\
\hline Auto and related & 3 & 1 & 1 \\
\hline Aviation/aerospace/Copper & 2 & 1 & 1 \\
\hline Beach \& minerals/metals & 2 & 0 & 2 \\
\hline Biotech & 32 & 0 & 21 \\
\hline Building Product/materials & 1 & 2 & 1 \\
\hline Electronic Product/industry & 3 & 0 & 3 \\
\hline Food Processing & 5 & 0 & 4 \\
\hline Footwear / Leather & 7 & 0 & 5 \\
\hline FTWZ & 14 & 5 & 7 \\
\hline Gems and Jewellary & 13 & 3 & 6 \\
\hline Granite Processing Industry & 2 & 0 & 1 \\
\hline Handicraft & 5 & 0 & 3 \\
\hline $\begin{array}{l}\text { IT/ITES/Electronic } \\
\text { Hardware/Semi conductor }\end{array}$ & 353 & 1 & 235 \\
\hline Metal/St.Steel/Alum/Foundary & 9 & 2 & 5 \\
\hline Metallurigal Engineering & 1 & 0 & 0 \\
\hline Multiproduct & 25 & 16 & 16 \\
\hline Multi services/Services & 16 & 3 & 9 \\
\hline Non conventional energy & 6 & 0 & 4 \\
\hline Petro chemical \& petro & 4 & 1 & 2 \\
\hline Pharma/Chemical & 23 & 3 & 20 \\
\hline Plastic Processing & 0 & 2 & 0 \\
\hline Port based multiproduct & 8 & 0 & 2 \\
\hline Power/alternate energy/solar & 3 & 2 & 3 \\
\hline Strategic Manufacturing & 0 & 1 & 0 \\
\hline Textiles/Apparel/Wool & 18 & 2 & 12 \\
\hline Writing \& Printing paper mills & 2 & 0 & 1 \\
\hline GRAND TOTAL & 588 & 49 & 386 \\
\hline
\end{tabular}

Source: Ministry of Commerce and Industry, SEZ in India, GOI

Note: IT/ITES/ Electronic Hardware/Semiconductor will not be displayed in the following figure for effective comparison of other Sectors 
Figure :2 Sector wise distribution of SEZ approvals

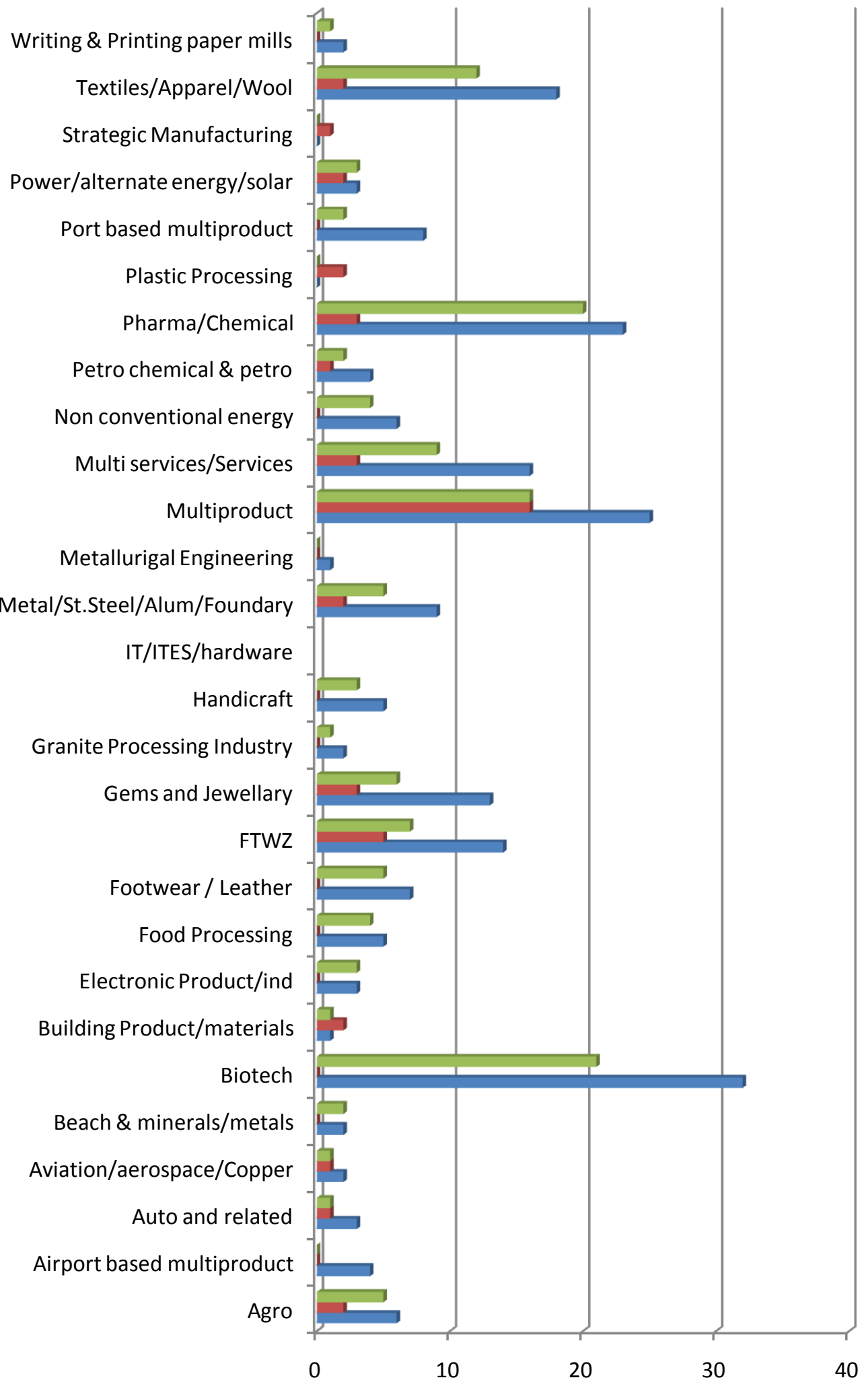

\section{Notified SEZ In Principle approval $\quad$ Formal approvals}




\section{Number of Formal Approvals of SEZs and their Average Size per State in 2008}

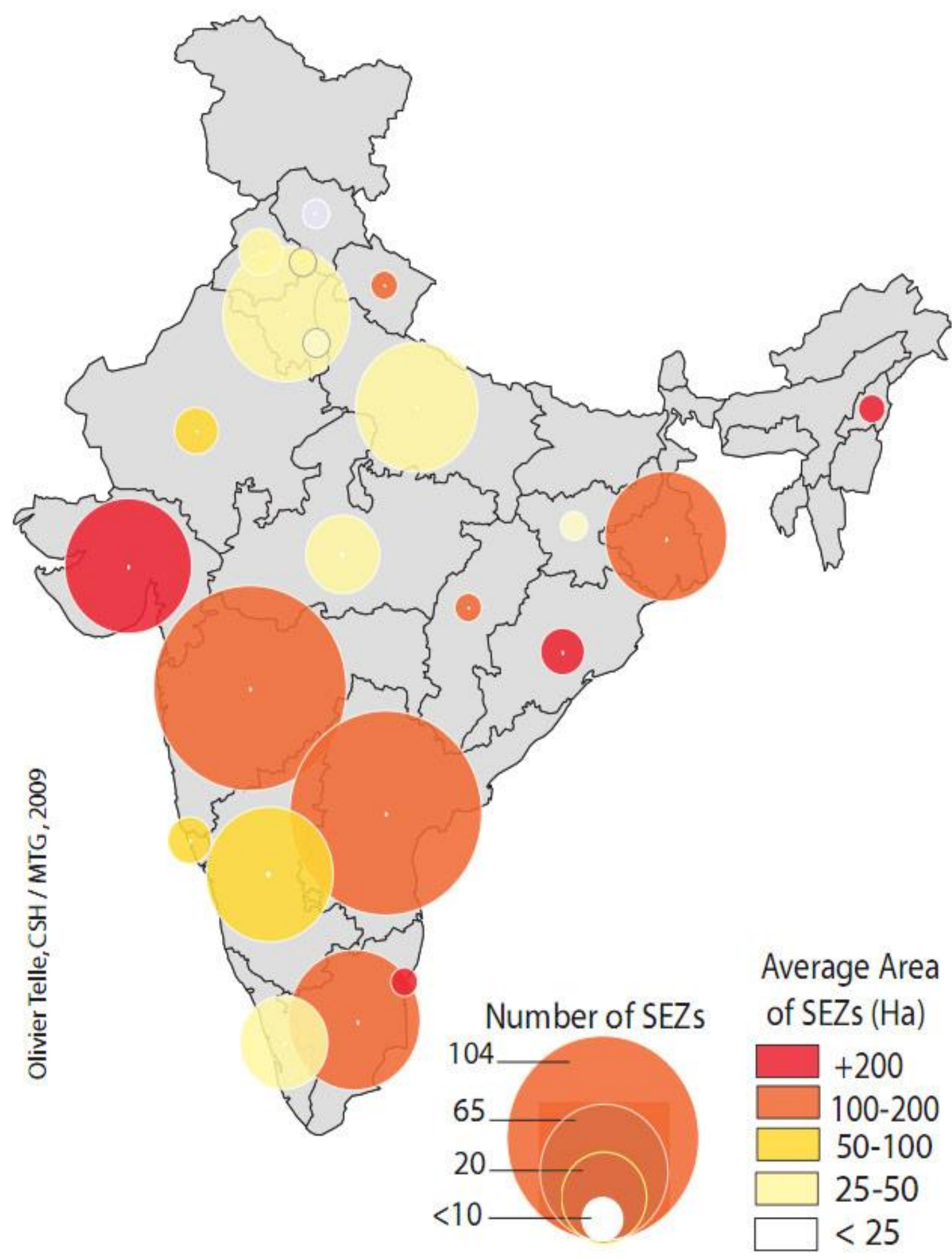

Source:Ministry of Commerce \& Industry, Government of India 


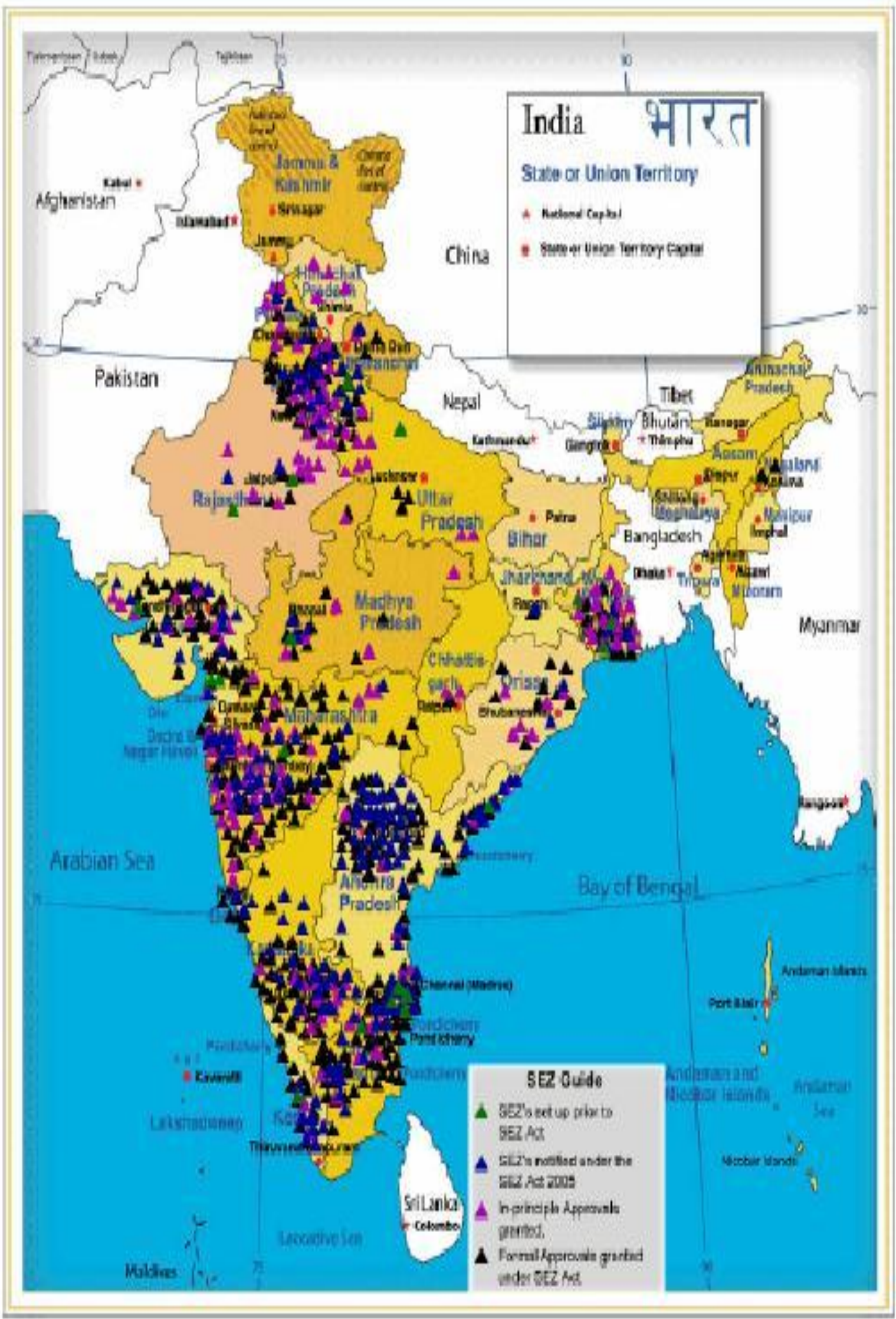

Source: Aseem Srivastava and Kas hif Ali 


\section{Conclusion}

The Emerging economic scenario of SEZ can be summarized with the following economic tools.

The current status of SEZ

\begin{tabular}{|l|l|}
\hline Number of Formal approvals & 589 \\
\hline $\begin{array}{l}\text { Number of Notified SEZs (as on 17 July } \\
\text { 2012) }\end{array}$ & 389 (out of 589) + (7 Central Govt. + 12 State/Pvt. SEZs) \\
\hline No. of Valid In-Principle Approvals & 48 \\
\hline $\begin{array}{l}\text { Operational SEZs (as on 31st March } \\
\text { 2012) }\end{array}$ & $\begin{array}{l}\text { 153 (Break up: 17 are multi product SEZs, remaining are } \\
\text { IT/ITES, Engineering, electronic hardware, textiles, } \\
\text { Biotechnology, Gem \& Jewellery and other sector } \\
\text { specific Special Economic Zones) }\end{array}$ \\
\hline $\begin{array}{l}\text { Units approved in SEZs (as on 31st } \\
\text { March 2012) }\end{array}$ & 3,400 \\
\hline
\end{tabular}

Source: Special Economic Zones in India, Ministry of Commerce \& Industry, Department of Commerce

Export Performance of SEZs

\begin{tabular}{|l|c|c|c|c|}
\hline \multicolumn{4}{|c}{ Exports from SEZs } \\
\hline & $2010-11$ & $\begin{array}{c}\text { \% of Total } \\
\text { production }\end{array}$ & $2011-12$ & $\begin{array}{c}\text { \% of Total } \\
\text { production }\end{array}$ \\
\hline \begin{tabular}{l}
\hline DTA Sale (Counted for +ve \\
NFE)
\end{tabular} & 29093.02 & 8.11 & 32472.70 & 8.00 \\
\hline $\begin{array}{l}\text { DTA Sale (Not counted for } \\
\text { +ve NFE) }\end{array}$ & 13881.20 & 3.87 & 29664.83 & 7.00 \\
\hline Total Exports & $3,15,867.85$ & --- & 364477.73 & ---- \\
\hline
\end{tabular}

Source: Special Economic Zones in India, Ministry of Commerce \& Industry, Department of Commerce

Employment generation of SEZ

\begin{tabular}{|l|l|l|}
\hline $\begin{array}{l}\text { Employment(as on 31st March } \\
\text { 2012) }\end{array}$ & Incremental Employment & Total Employment \\
\hline SEZs Notified under the Act & $5,52,048$ persons & $5,52,048$ persons \\
\hline $\begin{array}{l}\text { State/Pvt. SEZs set up before } \\
2006\end{array}$ & 66,547 persons & 79,015 persons \\
\hline Central Government SEZs & 91,617 persons & $2,13,853$ persons \\
\hline Total & $7,10,212$ persons & $8,44,916$ persons \\
\hline
\end{tabular}

Source: Special Economic Zones in India, Ministry of Commerce \& Industry, Department of Commerce

Investment in SEZ

\begin{tabular}{|l|l|l|}
\hline $\begin{array}{l}\text { Investment (as on 31st March } \\
\text { 2012) }\end{array}$ & \multicolumn{1}{|c|}{ Incremental Investment } & Total Investment \\
\hline SEZs Notified under the Act & US\$ 32.79 billion & US\$ 32.79 billion \\
\hline $\begin{array}{l}\text { State/Pvt. SEZs set up before } \\
2006\end{array}$ & US\$ 1.06 billion & US\$ 1.37 billion \\
\hline Central Government SEZs & US\$ 1.65 billion & US\$ 2.06 billion \\
\hline Total & US\$ 35.54 billion & US\$ 36.27 billion \\
\hline
\end{tabular}

Source: Special Economic Zones in India, Ministry of Commerce \& Industry, Department of Commerce 


\section{End Notes}

1. Special Economic Zone (SEZ) is defined as "a specifically delineated duty free enclave and shall be deemed to be foreign territory for the purposes of trade operations and duties and tariffs". SEZs are an acknowledgement of the potential of export-led development strategy in accelerating economic growth.

2. Taken from the introduction to Special Economic Zones in India: http://www.sezindia.nic.in/ HTMLS/about.htm (last viewed on 12th July 2007).

3. As on October13, 2011, there were 588 formal approvals of SEZs in the country. Out of this, 386 SEZs were notified. The number of valid In-Principle approvals was 49

4. The new law allows the SEZs to have area of the order of 1000 hectares for multi-product zones, 100 hectares for product specific zones and only 10 hectares for IT, gems and jewellery and biotechnology zones.

\section{References}

[1]. Aggarwal Aradhana (2004). Export Processing Zones in India: Analysis of the Export Performance. - Working Paper No. 148. New Delhi: ICRIER.

[2]. Aggarwal, Aradhna (2006), 'Special Economic Zones:Revisiting the Policy Debate', Economic and Political Weekly, November 4, pp. 4533-4536.

[3]. Arora, O P (2003). Compilation of Circulars on EPZ/SEZ/EOU issued by CBEC, DGFT \& RBI. Published byM/s Anmkur Arora Associates.

[4]. Aseem Shrivastava (2007), http://www.infochangeindia.org/analysis 167.jsp) raises the following questions regarding the SEZs.

[5]. Ashok Upadhyay (2005), Special Economic Zones--An idea whose time has lapsed, Business Line, Tuesday, December 20.

[6]. Asian Productivity Organization (1983), Economic and Social Impacts of Export Processing Zones in Asia, APO, Tokyo.

[7]. Bhandari, Anup Kumar and Pradip Maiti (2007). Efficiency of Indian Manufacturing Firms: Textile Industry as a Case Study. International Journal of Business and Economics, 6 (1): 71-88.

[8]. Goldar, B, V S Ranganathan and R Banga (2003). Ownership and Efficiency in Engineering Firms in Indian, 1990-91 to 1999-2000. ICRIER working Paper No. 115.

[9]. Grasset, Jeremy and Frederic Landy (2007). Special Economic Zones in India-Between International Integration and Real Estate Speculation. Man and Development, 29 (4): 63-74.

[10]. IIFT (1990). Exports Processing Zones in India: A Case Study of Kandla Free Trade Zone. Indian Institute of Foreign Trade Occasional Paper. New Delhi.

[11]. Kambhampati Uma S (2003). Trade Reforms and Efficiency of Firms in India. Oxford Development Studies, 31(2): 219-33.

[12]. Kumar, Ranjan (2006), 'SEZ: Capturing me Foreign Market',Southern Economist, September, Vol. 45.

[13]. Tantri, Malini L (2010): "Effectiveness of SEZs over EPZs Structure: The Performance at Aggregate Level”, ISEC Working Paper 248, Institute for Social and Economic Change (ISEC), Bangalore

[14]. Trivedi Pushpa (2004): “An Inter State perspective on Manufacturing Productivity in India: 1980-81 to 2000-01”, Indian Economic Review, 39(1): 203-237

[15]. Venugopal Dhoot (2007), ASSOCHAM Guidelines to improve SEZs, India Real Estate forum 7th March. Wall, David (1991), Special Economic Zones in Chinathe Administrative and Regulatory Framework, Research School of Pacific Studies, The Australian National University.

[16]. www.mepz.com

[17]. www.sez.nic.in 